\title{
Correction to: How has COVID-19 affected the treatment of osteoporosis? An IOF-NOF-ESCEO global survey
}

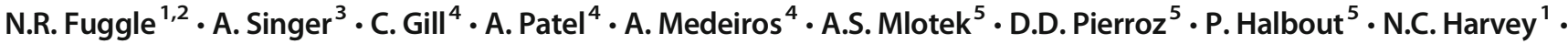 \\ J.-Y. Reginster ${ }^{6,7} \cdot$ C. Cooper ${ }^{1,8} \cdot$ S.L. Greenspan ${ }^{9}$
}

Published online: 9 March 2021

(C) The Author(s) 2021

\section{Correction to: Osteoporosis International (2021) https://doi.org/10.1007/s00198-020-05793-3}

The original version of this article, published on February 8, 2021, contained a mistake. The spelling of Nick C. Harvey's name was incorrect. The original article has been corrected.

Open Access This article is licensed under a Creative Commons Attribution 4.0 International License, which permits use, sharing, adaptation, distribution and reproduction in any medium or format, as long as you give appropriate credit to the original author(s) and the source, provide a link to the Creative Commons licence, and indicate if changes were made. The images or other third party material in this article are included in the article's Creative Commons licence, unless indicated otherwise in a credit line to the material. If material is not included in the article's Creative Commons licence and your intended use is not permitted by statutory regulation or exceeds the permitted use, you will need to obtain permission directly from the copyright holder. To view a copy of this licence, visit http://creativecommons.org/licenses/by/4.0/.

Publisher's note Springer Nature remains neutral with regard to jurisdictional claims in published maps and institutional affiliations.

The online version of the original article can be found at https://doi.org/ 10.1007/s00198-020-05793-3

C. Cooper

cc@mrc.soton.ac.uk

1 MRC Lifecourse Epidemiology Unit, University of Southampton, Southampton, UK

2 Alan Turing Institute, London, UK

3 Departments of Medicine and Obstetrics and Gynecology, MedStar Georgetown University Hospital, Georgetown University Medical Center, Washington, DC, USA

4 National Osteoporosis Foundation, Arlington, VA, USA

5 International Osteoporosis Foundation, Nyon, Switzerland

6 WHO Collaborating Center for Public Health Aspects of Musculo-Skeletal Health and Ageing, University of Liège, Liege, Belgium

7 Biochemistry Department, College of Science, King Saud University, Riyadh, Kingdom of Saudi Arabia

8 NIHR Musculoskeletal Biomedical Research Unit, University of Oxford, Oxford, UK

9 Department of Medicine, University of Pittsburgh, Pittsburgh, PA, USA 